\title{
EVALUATION OF THE BERRY CREEK-OWL CREEK \\ CUTTHROAT TROUT FISHERY \\ IN GRAND TETON NATIONAL PARK
}

\author{
Wayne A. Hubert \\ Department of Zoology and Physiology \\ and
}

Wyoming Cooperative Fishery and Wildlife Research Unit

University of Wyoming

Laramie

\section{Objectives}

Little is known about the wild cutthroat trout fishery of Berry Creek and OwI Creek located in Grand Teton National Park. No baseline information has been gathered on fishing pressure, harvest, population structure or life history characteristics for stocks from either stream. The creeks have a reputation for quality cutthroat trout (Salmo clarki) fishing. Wild trout fisheries are highly susceptible to over-harvest and relatively little fishing pressure can cause stock composition to be dominated by subcatchable-sized fish.

The goal of this project was to gather baseline information which could be used in assessing the current fishery conditions and in establishing future trends. As a result, informed management decisions regarding this and similar fisheries could be developed by the National Park Service and the Wyoming Game and Fish Department. To accomplish this goal five major objectives were identified:

1) Estimate the 1984 fishing pressure and harvest of cutthroat trout in Berry Creek and Owl Creek;

2) Describe behavioral attributes of fishermen utilizing the streams such as tackle used, catch and release attitudes, distribution along the creeks, and frequency and duration of trips;

3) Estimate annual mortality rate, growth rate and body condition of cutthroat trout in the two creeks;

4) Describe the location and timing of cutthroat trout spawning in the creeks; and

5) Describe the current fish community in Owl and Berry Creeks.

\section{Methods}

From June 23, 1984 to September 2, 1984 a creel survey was conducted at the access points of the trails to the two meadow areas within Grand Teton National Park. One access was located at the mouth of Berry Creek on Jackson Lake and the other was located on the Grassy Lake trail where the trail forks to go to Berry Creek Canyon. Four days out of each week (including weekends) were spent alternating between the two access points. Data collected during the creel survey periods was statistically expanded to estimate the total amount of 
fishing pressure and harvest of cutthroat trout during the summer of 1984. The estimates were computed with their associated stand and error.

In addition to the systematic survey, one day each week was devoted to hiking to one of the two meadow areas in order to survey fishermen at the fishing locations. Whenever a fisherman was encountered at an access point or on the stream he was interviewed to determine the number of hours fished, number of fish caught and kept, number of fish caught and released, type of tackle used, fishing location on the creeks, frequency of trips to the Berry-Owl Creek area, and the fisherman's home residence. Also, fish in the fisherman's possession were weighed and measured and a scale sample was taken.

On the days that the creel clerk hiked to the meadow sections of each creek, several observations were made. Stream characteristics were observed and measured. Spawning behavior was assessed by visual observation of redd construction and attendance by trout. The temporal occurrence of ripe female and male trout caught by fishermen and collected by the creel clerk was also noted to infer spawning behavior. Sampling with hook and line and with a seine was conducted at several locations along the length of each creek to evaluate the occurrence of different fish species and their relative abundance. All fish were released with the exception of type specimens kept to verify species identifications.

In early September, 1984, three separate 75-meter sections in each of the two meadow areas were electrofished to determine the cutthroat trout population structure and density. All fish collected were weighed and total length (TL) was measured. In addition scale samples were taken.

Using scales collected during the creel census and by electrofishing, fish age and growth was calculated. Standard length and weight relations, as well as condition factors, were computed.

\section{$\underline{\text { Results }}$}

A total of five fishing parties (11 fishermen) were interviewed during the 72 -day survey period of (June 23, 1984 - September 2, 1984). One of the five interviewees was judged to have given inaccurate information on fish catch and the interview was used only in the calculation of fishing pressure. A total of $29+18.6$ fishing days were estimated to have occurred. A fishing day was defined as one day of fishing by one angler. Anglers fished an average 2.7 hours per fishing day. The amount of fishing days was nearly equally divided between the two meadow areas with $55 \%$ of the fishing days on the meadow at the mouth of $\mathrm{OWl}$ Creek and 458 on the Upper Berry Creek meadow. There were an estimated 3.3 fishing days (9 fishing hours) per kilometer of stream and 4.4 fishing days (12 fishing hours) per hectare of stream in the Berry-Owl Creek meadows during 1984.

The estimated harvest of cutthroat trout from both creeks during the survey period was $44+29$ fish. The estimated biomass of all trout harvested was 12 kilograms (1.4 kilograms per kilometer of stream, 1.8 kilograms per hectare of 
stream) within the meadow areas.

Fishermen kept most of the trout they caught, especially the larger ones. Sixty-nine percent of the cutthroat trout caught were kept by the fishermen. Of the trout reported to have been caught and released, the majority were under $20 \mathrm{~cm}$ TL with $78 \%$ of the fish less than $20 \mathrm{~cm}$ released. Forty-five percent of the trout caught that were 20-30 cm TL were released and no fish over $30 \mathrm{~cm}$ was reported to have been released.

Only fly-fishing and spinning tackle were used by anglens observed ( 64 \% using spinners; $36 \%$ flyfishing) during 1984.

None of the fishermen interviewed had ever fished the Berry-Owl Creek system before. Twenty-seven percent of the fishermen resided within 100 miles of the creeks. The rest (73\%) came from more than 1000 miles away. No anglers entering the Berry and OWl Creek area from the Idaho side of the Tetons were observed. However, the backcountry ranger (Personal Communication, Ralph Moore, Grand Teton National Park) did report encountering one man who entered from the Idaho side of the Grand T'etons fishing the Upper Berry Creek meadow in 1984, so some fishing pressure occurs from this source.

The majority of the fish caught or reported were in the $20-30 \mathrm{~cm}$ TL range. No trout greater than $40 \mathrm{~cm}$ TL were observed, reported, or captured during the project.

Scales samples from 30 fish were used for age and growth analysis. Fish with It to IV+ annuli were observed in the sample.

The length-weight relationship of the cutthroat trout sampled was described by the following equation:

$$
\log (\text { weight })=-5.17+3.08 \log (\text { total length })
$$

where weight is measured in grams and total length in millimeters. The overall mean condition factor was 1.03.

During trips to the meadow areas, observations were attempted on cutthroat trout spawning activity. However, no spawning activity was observed. Ripe female trout were collected on August 8 and 17, 1984, giving some indication of late spawning activity. Several ripe males were caught in late August.

Only two species of fish were collected, cutthroat trout and mottled sculpin (Cottus bairdi). The population density of both species was so low that the depletion method of estimating fish abundance did not produce accurate estimates. Instead, only a very rough approximation of fish population density was made. We estimated that there was less than 100 cutthroat trout per kilometer in the meadow areas of Berry and Owl Creeks. This value represents a trout biomass of less than $10 \mathrm{~kg} / \mathrm{km}$ less than $15 \mathrm{~kg} / \mathrm{ha}$ ). Only $46 \%$ of the fish captured were considered a catchable size $(2200 \mathrm{~mm})$. Both meadow areas appeared to have low trout densities, but the Upper Berry Creek meadow had fewer fish than the meadow at the mouth of Owl Creek. No young of the year. 
cutthroat trout were collected by electrofishing from either meadow area and only two young-of-the-year fish were observed during the survey period.

\section{Conclusions}

Fishing pressure and harvest of cutthroat trout from Berry Creek and $0 \mathrm{wl}$ Creek was very low in 1984. Interviewed fishermen expreienced a high catch rate and tended to keep fish greater than $200 \mathrm{~mm} \mathrm{TL}$. Growth and condition of cutthroat trout from the two streams was about average for cutthroat trout stream fisheries. Spawning was not observed in the streams and very few young-of-the-year cutthroat trout were seen. The only other fish species observed was the mottled sculpin. Density of cutthroat trout was low, but only low gradient reaches were sampled. 